\title{
Single vital capacity breath for preoxygenation
}

Anis Baraka MD FRCA, Sanié Haroun-Bizri MD, Samar Khoury MD, Imad Rachid Chehab MD

Purpose: The report investigates, in awake patients before induction of anesthesia, the effect of preoxygenation by the single vital capacity breath technique following forced exhalation on the mean arterial $\mathrm{PO}_{2}\left(\mathrm{PaO}_{2}\right)$.

Methods: In 10 adult patients undergoing elective surgery, the mean $\mathrm{PaO}_{2}$ values achieved $30 \mathrm{sec}$ after preoxygenation by the single vital capacity breath technique was compared with the mean $\mathrm{PaO}_{2}$ values achieved by preoxygenation by the traditional tidal volume breathing for three minutes. Each patient served as her/his own control.

Results: The mean $\mathrm{PaO}_{2}$ following the single vital capacity breath technique was higher $(295 \pm 67 \mathrm{mmHg}$ ) than that achieved by the traditional tidal volume breathing technique at $30 \mathrm{sec}$ and $60 \mathrm{sec}$, and was not significantly different from that achieved by the traditional technique after three minutes $(307 \pm 70 \mathrm{mmHg})$.

Conclusion: The single vital capacity breath technique following forced exhalation can rapidly provide adequate preoxygenation within $30 \mathrm{sec}$.

Objectif : Étudier, chez des patients éveillés et avant l'induction de l'anesthésie, l'effet de la préoxygénation sur la $\mathrm{PO}_{2}\left(\mathrm{PaO}_{2}\right)$ artérielle moyenne, par l'utilisation d'une inspiration à capacité vitale suivant une expiration forcée. Méthode : Chez 10 adultes, admis pour une intervention chirurgicale planifiée, les valeurs moyennes de la $\mathrm{PaO}_{2}$ obtenues $30 \mathrm{~s}$ après une préoxygénation selon la technique de la capacité vitale ont été comparées aux valeurs moyennes de la $\mathrm{PaO}_{2}$ obtenues à la suite d'une préoxygénation par l'utilisation traditionnelle du volume courant pendant trois minutes. Chaque patient était son propre témoin.

Résultats : $\mathrm{La} \mathrm{PaO}_{2}$ moyenne mesurée avec la capacité vitale était plus élevée ( $295 \pm 67 \mathrm{mmHg}$ ) que celle qui résultait de la mesure du volume courant à $30 \mathrm{~s}$ et à $60 \mathrm{~s}$, mais elle ne présentait pas de différence significative avec la mesure traditionnelle après trois minutes $(307 \pm 70 \mathrm{mmHg}$ ).

Conclusion : L'inspiration à capacité vitale suivant une expiration forcée peut fournir rapidement une préoxygénation suffisante en moins de $30 \mathrm{~s}$.

From the Department of Anesthesiology, American University of Beirut, P.O. Box 113-6044, Beirut, Lebanon. Address correspondence to: Anis Baraka mD FrCA. Phone: 961-1-374374, Ext. 6380; Fax: 961-1-744464; E-mail: abaraka@aub.edu.lb Accepted for publication August 15, 2000. 
HE single vital capacity breath technique has been popularized for rapid induction of inhalation anesthesia. Patients exhale to residual volume and then inhale a high concentration of an anesthetic such as sevoflurane to vital capacity and hold the chest in this inspiratory position as long as possible. ${ }^{1-4}$ Theoretically, by minimizing the amount of air in the lungs before inhalation of a vital capacity breath, dilution of the inspired anesthetic gases with air is held to a minimum and alveolar concentration of the anesthetic is maximized. ${ }^{2}$

The rationale of the single vital capacity breath (SVCB) technique may be utilized for rapid preoxygenation. The present report compares the arterial oxygen tensions following preoxygenation with the SVCB technique to that achieved by traditional tidal volume breathing technique.

\section{Method and material}

The study was approved by our institutional review committee, and informed consent was obtained from all patients. The investigation was carried out on 10 male patients, aged $55-65 \mathrm{yr}$, scheduled for elective coronary artery bypass grafting, and had no evidence of congestive heart failure or lung disease.

Patients were premedicated with $\left(0.1 \mathrm{mg} \cdot \mathrm{kg}^{-1}\right)$ morphine $25 \mathrm{mg}$ promethazine and $0.2 \mathrm{mg}$ glycopyrrolate $\mathrm{im}$. Before induction of anesthesia, arterial blood gas analysis was done while breathing room air. All patients were then instructed about the two techniques of preoxygenation. Each patient underwent the two techniques in a random order, separated by five minutes breathing room air. An arterial blood gas sample on room air was taken to ensure a return to baseline before applying the second technique. Each patient served as his own control.

An adult Mapelson D circuit, ${ }^{5}$ with a 2 L capacity reservoir bag was used for the two techniques of preoxygenation. Before preoxygenation, the anesthesia circuit was flushed with oxygen and the reservoir bag was filled to capacity by occluding the mask opening with the palm of the hand. The traditional preoxygenation technique consisted of three minutes of tidal volume breathing, using an oxygen flow of $5 \mathrm{~L} \cdot \mathrm{min}^{-1}$ with a good face mask seal. Arterial blood gases were analyzed at $30 \mathrm{sec}$, one, two and three minutes. In the SVCB technique, the patients exhale forcibly to room air down to their residual volume. The face mask connected to the anesthesia circuit delivering oxygen 10 $\mathrm{L} \cdot \mathrm{min}^{-1}$ was then firmly applied, and the patients were asked to take a vital capacity breath and to hold it for $30 \mathrm{sec}$. CPAP was not induced, and additional oxygen was occasionally supplied from the oxygen flush device if the reservoir bag was nearly empty. At $30 \mathrm{sec}, \mathrm{ABGs}$ were analyzed. The mean $\mathrm{PaO}_{2}$ achieved following the SVCB at $30 \mathrm{sec}$ were compared with that achieved by traditional tidal volume breathing at $30 \mathrm{sec}$, one, two and three minutes.

\section{Statistical analysis}

The mean $\mathrm{PaO}_{2}$ before and after preoxygenation with traditional tidal volume breathing were compared using analysis of variance with repeated measurements. The mean $\mathrm{PaO}_{2}$ before and following preoxygenation by the SVCB were compared using the Students $t$ test. The $t$ test was also used to compare the $\mathrm{PaO}_{2}$ achieved by preoxygenation by the SVCB with that achieved by the traditional technique. $P$ $<0.05$ was considered significant.

\section{Results}

There was no difference between the baseline mean $\mathrm{PaO}_{2}$ values on room air prior to the single vital capacity breath technique $(91 \pm 18 \mathrm{mmHg})$ and the tidal volume breathing technique $(83 \pm 17 \mathrm{mmHg})$. The figure depicts the mean $\mathrm{PaO}_{2}$ values vs time following preoxygenation by the SVCB technique $v s$ the traditional tidal volume breathing technique.

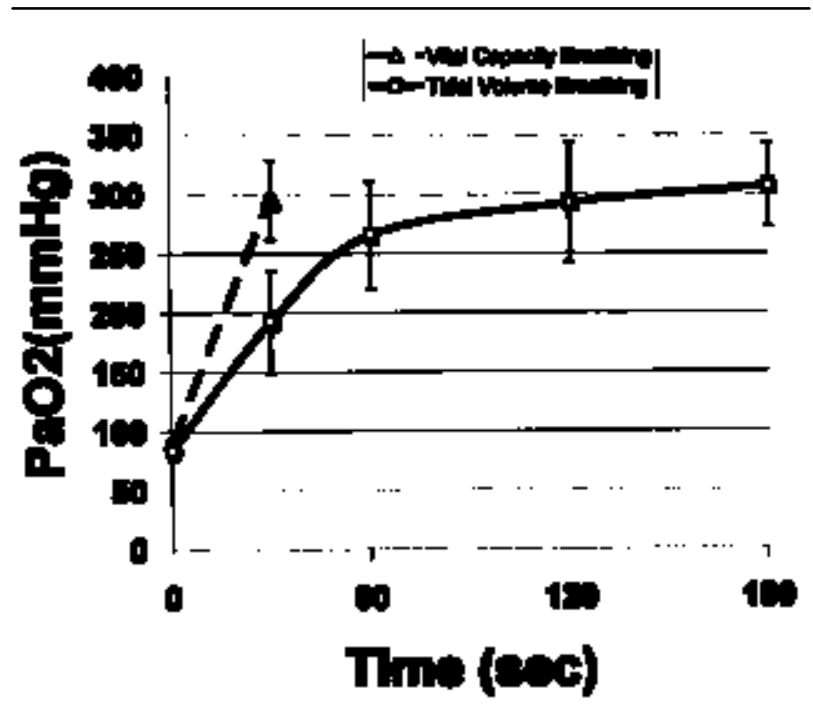

FIGURE. Mean $\mathrm{PaO}_{2} \pm \mathrm{SD}$ at 30,60,120, and $180 \mathrm{sec}$ follow ing the traditional tidal volume breathing technique of preoxygenation. The increase of $\mathrm{PaO}_{2}$ is exponential as shown by the hard line which represents the logarithmic fit of $\mathrm{PaO}_{2}$ values vs time.

The diagram also shows the mean $\mathrm{PaO}_{2} \pm \mathrm{SD}$ achieved after 30 sec by the single vital capacity breath technique, as compared to the mean $\mathrm{PaO}_{2}$ values achieved by the traditional preoxygenation technique. 
Preoxygenation with traditional tidal volume breathing increased the $\mathrm{PaO}_{2}$ in an exponential fashion; the mean $\mathrm{PaO}_{2}$ values at $30 \mathrm{sec}(192 \pm 85$ $\mathrm{mmHg}$ ), one minute $(265 \pm 90 \mathrm{mmHg}$ ), two minutes $(293 \pm 100 \mathrm{mmHg})$ and three minutes $(307 \pm 70$ $\mathrm{mmHg}$ ) were higher than the baseline $\mathrm{PaO}_{2}$ breathing room air. Following preoxygenation with the SVCB technique, the mean $\mathrm{PaO}_{2}$ at $30 \sec (295 \pm 67$ $\mathrm{mmHg}$ ) was higher than that achieved after $30 \mathrm{sec}$ and $60 \mathrm{sec}$ of tidal volume breathing, and was not different from that achieved after two to three minutes of tidal volume breathing.

\section{Discussion}

Traditional preoxygenation can be achieved by breathing at normal tidal volumes using an oxygen flow of $51 \cdot \mathrm{min}^{-1}{ }^{6}$ Preoxygenation denitrogenates the functional residual capacity (FRC) in an exponential fashion, and hence increases the FRC oxygen store. Denitrogenation is $95 \%$ complete within two to three minutes. ${ }^{6}$

Rapid preoxygenation can be achieved by using four deep breaths within $30 \mathrm{sec}$ at an oxygen flow of $51 \cdot \min ^{-17}$ Baraka et al. optimized the deep breath technique by using eight deep breaths within $60 \mathrm{sec}$ at an oxygen flow of $10 \mathrm{l} \cdot \mathrm{min}^{-1}$; the $\mathrm{PaO}_{2}$ after the eight deep breaths technique was not different from that achieved following the traditional three minutes of tidal volume breathing. ${ }^{8}$

Maximal expiration before application of the face mask has been shown to improve preoxygenation when the four vital capacity breath technique is used. ${ }^{9}$ The present report also shows that forced exhalation before the SVCB technique can provide within $30 \mathrm{sec}$ a mean $\mathrm{PaO}_{2}$ value comparable with that achieved by tidal volume breathing for two to three minutes.

Preoxygenation by the SVCB technique is a triphasic process. The first phase consists of forced exhalation to room air which decreases the alveolar volume from the FRC down to the residual volume. 9 This maneuvre minimizes lung nitrogen content and the subsequent dilution of incoming oxygen. The second phase of preoxygenation is achieved by the SVCB which expands the lung to its total capacity, with a consequent maximal increase of the alveolar oxygen concentration which is the main oxygen store in the body. ${ }^{10}$ Finally, holding the chest in full inspiratory position may increase the alveolar/capillary oxygen diffusion. The breath hold also allows for pendoluft maximisation, since the time constants of filling between the alveoli are not uniform.

The rationale of the single vital capacity breath technique for rapid induction of inhalation anesthesia or rapid preoxygenation is essentially the same. Thus, the SVCB technique can provide speed induction of anesthesia associated with rapid preoxygenation, whenever a high concentration of sevoflurane in 100\% oxygen is used. The speed of induction of sevoflurane anesthesia by the SVCB technique is not significantly different whether nitrous oxide: oxygen or $100 \%$ oxygen is used. ${ }^{4}$

In conclusion, the present report shows that preoxygenation by the SVCB technique following forced exhalation can rapidly provide $\mathrm{PaO}_{2}$ values comparable to that achieved by the traditional tidal volume breathing. The technique can optimize oxygenation whenever the SVCB is used for fast induction of inhalational anesthesia.

\section{References}

1 Yurino M, Kimura $H$ Induction of anesthesia with sevoflurane, nitrous oxide, and oxygen: a comparison of spontaneous ventilation and vital capacity rapid inhalation induction (VCRII) techniques. Anesth Analg 1993; 76: 598-601.

2 Yurino M, Kimura $H$ A comparison of vital capacity breath and tidal breathing techniques for induction of anaesthesia with high sevoflurane concentrations in nitrous oxide and oxygen. Anaesthesia 1995; 50: 308-11.

3 Philip BK, Lombard LL, Roaf ER, Drager LR, Calalang I, Philip JH. Comparison of vital capacity induction with sevoflurane to intravenous induction with propofol for adult ambulatory anesthesia. Anesth Analg 1999; 89: 623-7.

4 Yurino M, Kimura $H$ Comparison of induction time and characteristics between sevoflurane and sevoflurane/ nitrous oxide. Acta Anaesthesiol Scand 1995; 39: 356-8.

5 Baraka $\mathrm{A} \mathrm{PCO}_{2}$ control by fresh gas flow during controlled ventilation with a semi-open circuit. $\mathrm{Br} \mathrm{J}$ Anaesth 1969; 41: 527-9.

6 Hamilton WK, Eastwood DW. A study of denitrogenation with inhalation anesthetic systems. Anesthesiology 1955; 16: 861-7.

7 Gold MI, Duarte I, Muravchick S. Arterial oxygenation in conscious patients after 5 minutes and 30 seconds of oxygen breathing. Anesth Analg 1981; 60: 313-5.

8 Baraka A, Taha SK, Aonad MT, El-Khatib MF, Kawkabani NI. Preoxygenation. Comparison of maximal breathing and tidal volume breathing techniques. Anesthesiology 1999; 91: 612-6.

9 McCrory JW, Matthews JNS. Comparison of four methods of preoxygenation. Br J Anaesth 1990; 64: 571-6.

10 Baraka A, Aouad M, Taba S, El-Khatib M, Kawkabani $N$, Soneidi A Apnea-induced hemoglobin desaturation during one-lung $v s$ two-lung ventilation. Can J Anaesth 2000; 47: 58-61. 